\title{
Influence of Foundation Settlements in Load Redistribution on Columns in a Monitoring Construction - Case Study
}

\section{Influência dos Recalques de Fundação na Redistribuiçao de Cargas nos Pilares numa Construção Monitorada - Estudo de Caso}
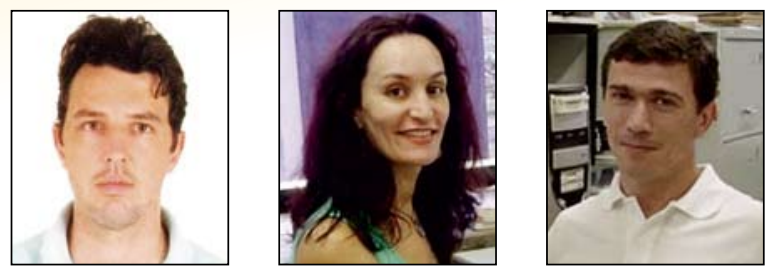

G. SAVARIS a

gustavosavaris@unipar.br

P. H. HALLAK* b patricia.hallak@ufjf.edu.br

P. C. A. MAIA maia@uenf.br

\begin{abstract}
The objective of this article is to present the results obtained in a study on the interaction between the behavior of the structure and the foundation settlements and verify the influence of normal load distribution on the columns. In this mechanism, known as structure soil interaction (SSI), as the building is constructed, a transfer of loads occurs from the columns which tend to settle more to those that tend to settle less. The study was conducted in a building which had its settlements monitored from the beginning of construction. For this purpose, a linear tridimensional numerical model was constructed and numerical analysis was performed, using the finite elements method. In these analyses, numerical models corresponding to the execution of each floor were used, considering the settlements measured in each stage of the construction. The results of analyses showed that the effect of SSI are significant for calculating the normal efforts on the columns, particularly on those located in the first floors.
\end{abstract}

Keywords: structure soil interaction, settlements, reinforced concrete

\section{Resumo}

O objetivo deste artigo é o de apresentar os resultados obtidos do estudo da interação entre o comportamento da estrutura e os recalques de fundação e verificar a sua influência na redistribuição de esforços normais nos pilares. Neste mecanismo, conhecido como interação solo estrutura (ISE), a medida que a edificação é construída, ocorre uma transferência de cargas dos pilares que tendem a recalcar mais para aqueles que tendem a recalcar menos. $O$ estudo foi conduzido em um edifício que teve seus recalques monitorados desde o início da construção. Para se alcançar este objetivo, foi construído um modelo numérico linear tridimensional e foi realizada uma análise numérica pelo método dos elementos finitos. Nestas análises, modelos numéricos correspondentes a conclusão de cada andar foi utilizado em conjunto com os recalques medidos para cada etapa da construção. Os resultados das análises motraram que os efeitos da ISE são significantes para o cálculo dos esforços normais nos pilares, particularmente para aqueles localizados nos primeiros andares.

Palavras-chave: interação solo-estrutura, recalques, concreto armado.

a Universidade Paranaense - UNIPAR, Campus Cascavel, gustavosavaris@unipar.br, Rua Rui Barbosa $n^{\circ}$ 611, Cascavel, Paraná, Brasil.

Department of Applied and Computational Mechanics, Federal University of Juiz de For a - UFJF, patricia.hallak@ufjf.edu.br, Juiz de Fora,

Rua José Lourenço Kelmer, s/n Campus Universitário, Juiz de Fora, MG, CEP 36036 900, Brazil

Department of Civil Engineering, CCT, State University of Norte Fluminense Darcy Ribeiro - UENF, maia@uenf.br, Av. Alberto Lamego 2000, Campos dos Goytacazes, RJ, CEP 28013-600, Brazil

corresponding author 


\section{Introduction}

The growing real estate expansion and appreciation of land in the large urban centers have caused a market trend towards verticalization of buildings. Large buildings with audacious architectural projects and the reduction in construction costs have demanded more refined models for structural analysis from engineers responsible for calculations. Thus the development of new techniques and advancements in informatics has allowed projects to be drawn up with greater precision and faster calculations, directly influencing the safety and cost of the building.

Traditionally, building projects have been drawn up admitting that the supports on the ground are non-displaceable, resulting in a set of loads (vertical, horizontal reactions and flexural moments) which are passed to the foundation engineer who, considering the results obtained in the field trials, dimensions the foundations.

In the foundations, displacements are normally admitted, limited by the damage they may cause to the building. Nevertheless, any displacement in support causes disturbance in the structure. Generally, changes occur in the trajectories of stresses, culminating in the redistribution of internal efforts.

In reality, the performance of a building is governed by the interaction between the superstructure, infrastructure and foundation soil, in a mechanism denominated structure soil interaction (SSI). Through this mechanism, as the building is constructed, a transfer of loads occurs from the columns which tend to settle more to those that tend to settle less. These aspects have been studied by various authors, for example, MEYERHOF [1], CHAMECKI [2], GOSHY [3], GUSMÃO [4][5] and [6], DANZIGER et al. [7], GUSMÃO and CALADO JR [8] and GONÇALVES [9].

Load transfer between the columns causes a trend towards uniformization of settlements, resulting in smaller displacements than those estimated. This effect may be found when settlements of foundations are monitored during construction, and throughout the useful life of the building.

Normally, settlement monitoring in constructions is associated with the unsatisfactory performance of the foundations, with the occurrence of pathologies and need for strengthening. The main consequences of settlements are the appearance of cracks and excessive inclinations of buildings, the most common being the Tower of Pisa in Italy, and the buildings constructed in the City of Santos - SP, Brazil.

In conventional constructions, when no pathologies related to foundations occur, generally the settlements are not monitored, due to the constructor's concern with cost reduction and also due to the lack of a culture of settlement monitoring.

Nevertheless, monitoring building during construction, observing the behavior of the foundations as they are being loaded, in addition to serving as a certification of quality of the projects and execution of the construction, they are a great contribution to the study of the mechanism of interaction between the structure and soil.

\subsection{Justification}

This study is justified due to the few reports on the observation of behavior of engineering constructions on a natural scale, especially buildings, during the construction process. According to GUSMÃO [5] the main reports present the results of studies conducted in buildings due to the appearance of pathologies in the building, from cracks in the brickwork and damage to the structural elements.

In addition to this, several researchers into the subject have pointed out a standard behavior of the SSI mechanism, which is redistribution of forces on the columns. Thus, the less loaded columns in the conventional project tend to suffer an increase in load while the least loaded columns tend to suffer load relief. This behavior is a cause for concern from the structural point of view, and therefore deserves attention.

For a long time, the development of methodologies for analyzing structures has been based on the behavior of the elements and the damage that occurred, thus monitoring the behavior of foundations during construction will help to prepare more precise methods of structural analysis.

\subsection{Objectives}

Through this study, the intention is to present the results of a case study, evaluating the interaction between the behavior of the structure and the displacements of the foundations. Furthermore, the intention is to verify the influence of load redistribution among the pillars, contributing to the formation of a database about the behavior of building foundations in the Campos dos Goytacazes region, Brazil.

By means of a tridimensional numerical and linear analysis of the structure, by the finite element method, one seeks to quantify the variations in the load on foundations and pillars throughout construction. Through this study, one expects to help future research into the development of methodologies for analyzing the structure soil interaction in building projects.

Figure 1 - Soil structure interaction model

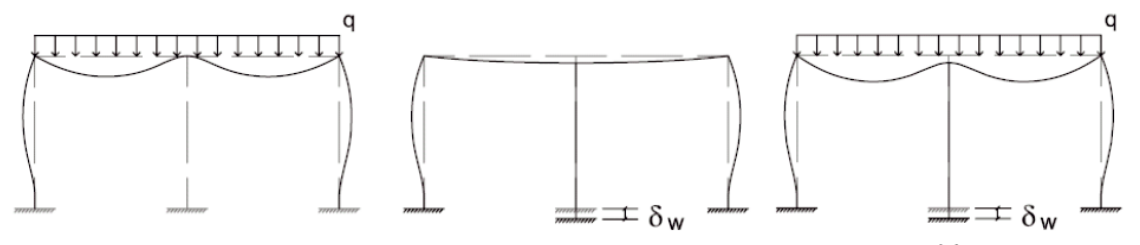

(a)

(b) 


\section{Figure 2 - Effect of SSI on settlements and support reactions (adapted from GUSMÃO (4))}

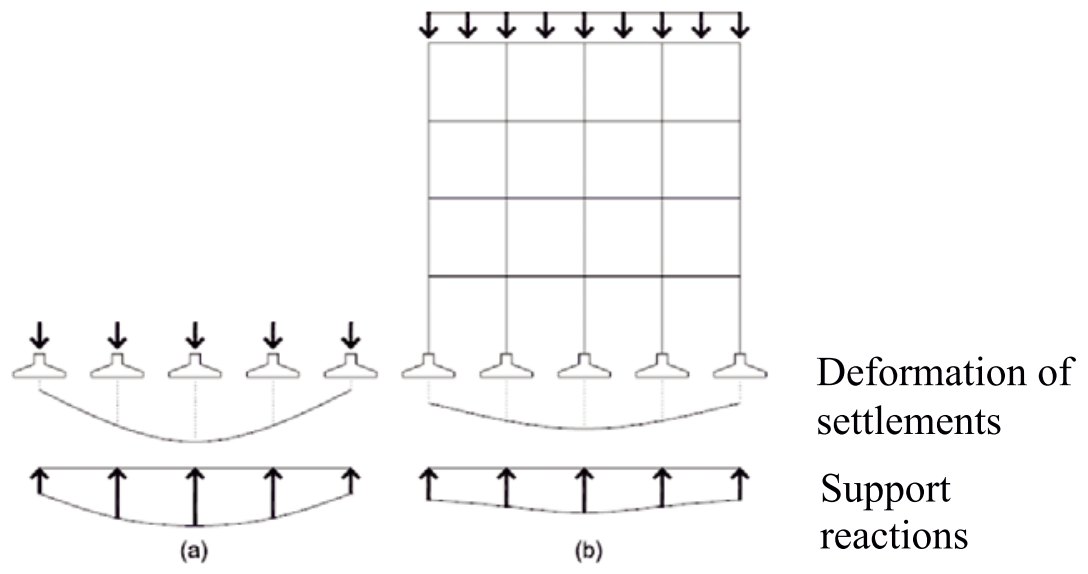

\section{Structure-Soil Interaction Mechanism (SSI)}

The structure-soil interaction mechanism can be observed, for example, by the statics analysis of a system composed of a beam supported by three columns, subjected to a uniformly distributed load, as presented in Figure [1a]. In this case, the load acting on the central column, determined by conventional statistical analysis, corresponds to twice the load on the lateral columns. Due to the higher load, the foundation of the central column tends to suffer greater displacements, however, depending on the magnitude of the beam rigidity, this displacement is restricted to causing transfer

\section{Figure 3 - Analogy with deep beam (3)}

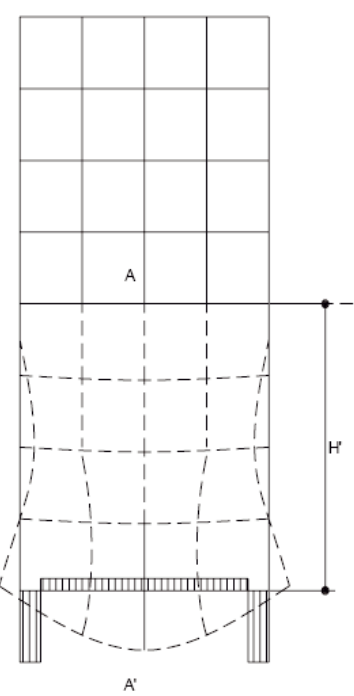

Section A A'

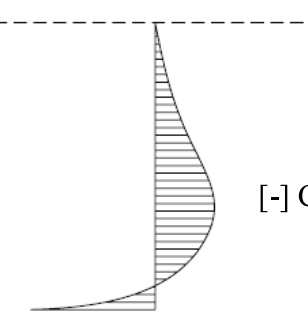

$[+]$ Traction

Obs.: $\mathrm{H}^{\prime}=$ influence height of loads to the lateral columns. Consequently, the displacement of the central column is smaller than expected, while the displacement of the lateral columns will be greater.

In addition to the effects of rigidity of the structure on the foundation displacements, these displacements will also influence the deformation of the structure. This can be observed when one compares the deformation of elements of the structure in Figure [1]. In a linear analysis one observes that the final conditions of deformation of a structure consist of the sum of the deformations of the elements, due to the loads and redistributions, and they can be obtained only by an interactive analysis of the soil-foundation-structure system. Thus, the study of settlements may be used as a tool for the analysis of the structure-soil interaction mechanisms. For this purpose, an initial forecast of the settlements is made, considering the isolated foundations, and monitoring the settlements of the building through the construction and useful life of the building.

The performance of any building can be evaluated by means of two models of analysis: in the first model (Figure [2a]) the foundations are dimensioned and the settlements estimated considering only the loading coming from the structure and in the second model (Figure [2b]) the stiffness of the structure is considered in the estimate of settlements. One verifies that the deformation of settlements becomes slighter due to the influence of the interaction of the soil and structure, with the central supports tending to settle less than forecast and the peripheral supports settling more.

The impediment of settlements caused by the rigidity of the structure alters the maximum and minimum settlements, and consequently the differential settlements. Nevertheless, the total mean estimated settlements do not alter significantly. Thus, the angular distortions caused by the differential settlements are minimized, making it feasible to achieve foundations that would not be possible to achieve by conventional studies [8].

The redistribution of forces on elements of the structure is a consequence of uniformizing the settlements. According to GOSHY [3], this occurs with greater intensity on the lower floors of buildings, where the open framed structure with panels behaves in the same way as vertical planes, similarly to a deep beam. Thus, the lower 
Table 1 - Consequences of the hypothesis of projects with regard the SSI (6)

Calculation Hypotheses Consequence

Supports considered non-displaceable

Supports may settle in a manner independent of one another

The loading of the building only occurs on conclusion of its construction
Redistribution of loads and forces on structural elements, especially beams and columns.

Load relief on most loaded columns and overload on less loaded columns.

There may be damage to structural elements.

The connection between structural elements gives the structure a rigidity that restricts differential settlements.

The deformation of settlements measured is slighter than that conventionally estimated.

There is a tendency towards uniformization of settlements.

As the structure is being constructed there will be an increase in its load and in the absolute settlements.

There is, however, an increase in the rigidity of the structure, which causes

a trend towards uniformization of the settlements.

There is a limit height, corresponding to the first five floors, at which there is practically no further increase in rigidity for the purposes of uniformizing the settlements. parts of the structure preferentially undergo flexural deformations, as shown in Figure [3].

According to GUSMÃO and CALADO JR. [8], the variation in the flexural moments, and torsional and cutting forces are negligible, in comparison with the axial forces. Redistribution of load on the columns generates the transfer of load from the supports that tend to settle more to those that tend to settle less. These increases in load are significant, and can attain variations of up to $30 \%$ in the load foreseen in the rigid model ([5] and [8]). These increases in loads can cause pathologies in the structural elements, such as cracking of beams and concrete slabs, and crushing of columns.

Determining the loads acting on the columns of buildings has been performed in two ways: by measuring the deformation of the columns, using defined concepts of material resistance for load determination, or by estimation or measurement of settlements, using computer programs for structural analysis, in which the settlements measured are applied as prescribed displacements on the supports.

In modeling the structure, some simplifications are generally made, directly related to the consequences on the final product built. Some of these simplified hypotheses and their respective consequences have been related by GUSMÃO [4] and are presented in Table 1. Thus, one observes the need for considering the interaction between the soil and the structure in drawing up building projects, with the goal, above all, of minimizing pathologies.

\section{Description of the Building Analyzed and Computational Modeling}

The study was developed in a residential building, named Edifício Classic, located in the city of Campos dos Goytacazes - RJ, Brazil.
In Figure [4] a photo of the building is presented, at the final finishing stage. Following the trend towards verticalization of buildings in the city, this building is constituted of 12 floors, constructed above the surface of the land. The land has a social entrance and the garages, which are also extended to the following two floors. After this, there are nine floors of the type composed of four residential units each, and the top floor apartment, with party area, machinery rooms and elevated reservoir.

\section{Figure 4 - Font elevation of Edificio Classic}

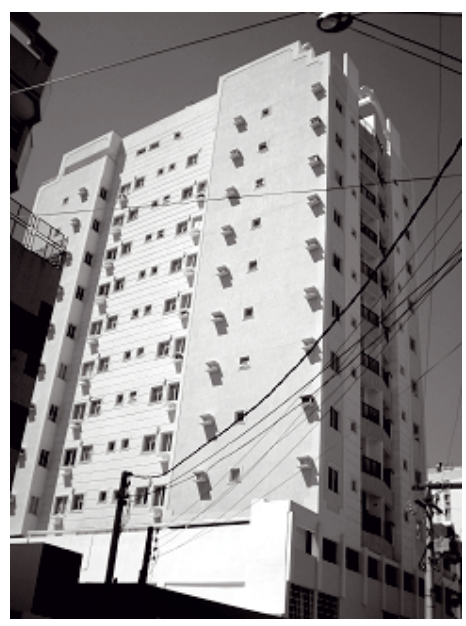




\section{Figure 5 - Sketches of the foundations, location of columns, level reference mark and piping network}

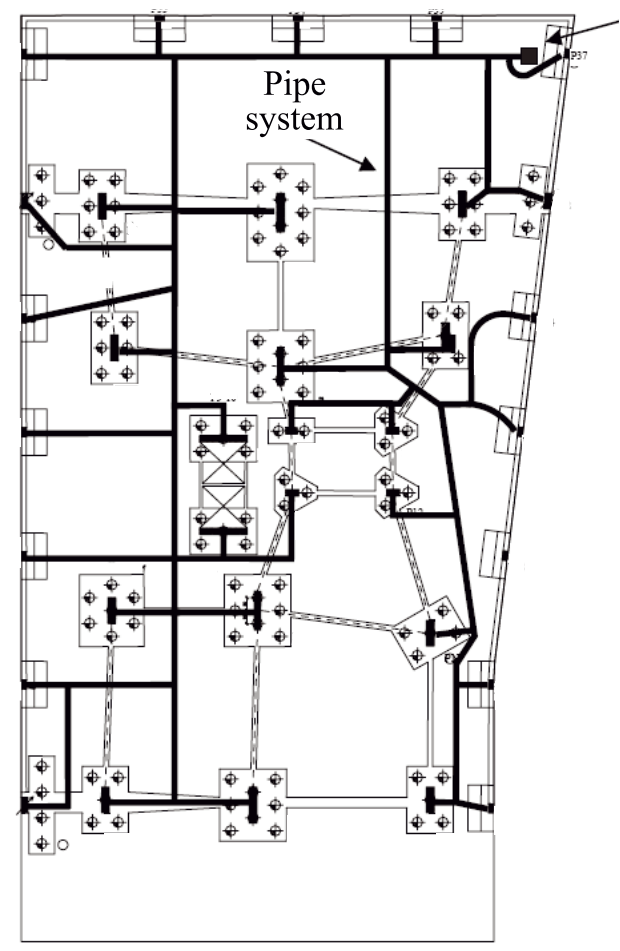

Benchmark level

\subsection{Features of the Structure}

The building structure is formed of columns, board beams, ramp and stairs of conventional reinforced concrete, smooth concrete decks and two prestressed reinforced concrete transition beams, using the non-adherent prestressed system with greased single cables. The building has 35 columns in the first three floors, starting with the foundations, and for each floor 18 columns follow, with the transition of three columns occurring on prestressed beams. Closure of the building and internal divisions has been done with brickwork using ceramic bricks with holes, and for closing the stairs, concrete blocks were used.

Figure [5] shows important details of the position of the foundations and hydraulic network of the hydraulic system for monitoring the settlements. Readers are invited to consult the original dissertation of SAVARIS [10] should they wish to obtain details about the settlement measuring system used in the study.

The foundation loads obtained by conventional design, it means, considering non-displaceable supports, range between $300 \mathrm{kN}$ and $5200 \mathrm{kN}$. Two types of foundations were designed and executed: dividing columns with footing foundation and central columns with piles. The footing foundations are seated at 1.80 from the surface of the land, on a compacted layer of soil, improved by the mixture of sand and cement. The piles were made by continuously monitored helical equipment, 400 $\mathrm{mm}$ in diameter, and mean depth of $12.5 \mathrm{~m}$, reinforced in the first three meters.

\subsection{Modeling of the Structure}

The Edifício Classic structure was described in finite elements, allowing a static numerical and linear analysis to be made, using a computer program for structural analysis.

The beams and columns were modeled as uniaxial bar elements, defined by two nodes located on the line that passes through the center of gravity of the section. These elements have traction, compression, torsion and flexion capacities. The elements have six degrees of freedom in each node, being three rotations and three translations. In the columns, the eccentricities of the beams were disregarded, except on the columns of the elevator box, in which rigid bar elements were inserted, which transfer the load from the beams directly onto the axes of the columns.

\section{Figure 6 - Tridimensional model of the 3rd, 7th and 12th}
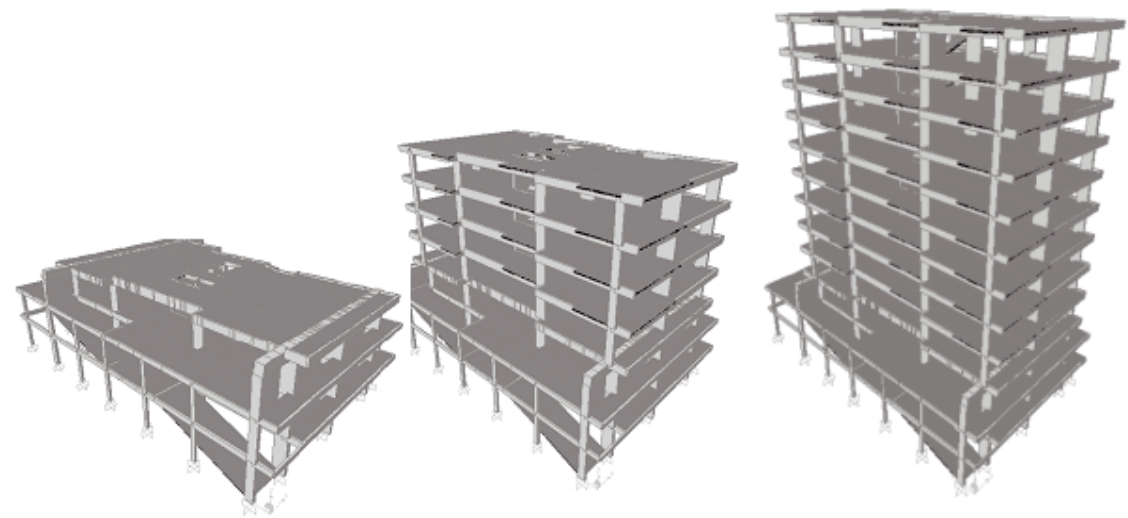
The concrete slabs were considered as plate elements, defined by four nodes, with six degrees of freedom in each node, being three rotations and three translations. These were discretised in quadrangular elements according to the tracing of the prestressing cables.

The structural analysis took into consideration the developmental process of the building through the development of twelve tridimensional models, corresponding to concreting of each of the concrete slabs of the building. Only the stages of construction in which the settlements of all the columns were monitored were considered. Figure [6] presents the models with reference to the $3^{\text {rd }}, 7^{\text {th }}$ and $12^{\text {th }}$ concrete slab respectively.

As the measurements of the settlements had been made in points located at the bottom extremity of the ground floor columns, the tridimensional models did not take into consideration the elements of foundation and soil, as they were considered the continuity of the structure at the points of measurement by the restriction of displacements and the rotations in the three directions of the overall system of reference.
By follow-up of the construction time schedule, data was obtained of the execution of the brickwork on each floor, presented in Table 2 , with the loads being entered due to the brickwork in the models with reference to the respective stages of the construction process. The wall was considered with a thickness of $12 \mathrm{~cm}$ for the internal divisions done with ceramic bricks, and $15 \mathrm{~cm}$ for the stair walls, constructed with blocks of mortar.

The weight of the structure itself was automatically calculated by the computer program from the dimensions of the elements and the physical properties of the materials. The accidental loadings were disregarded in the analyses. The specifications of the materials used in the construction were obtained from the architectural and structural projects, occasionally for the materials with non specified properties, the recommendations of the Brazilian Standards NBR 6118 [11] and NBR 6120 [12] were adopted, as presented in Table 3.

The prestressing performed in the concrete slabs and transition beams was considered as a Set of Equivalent Concentrated Loads, as presented by MENEGATTI [13]. This methodology proposed for

\section{Table 2 - Important construction data}

\begin{tabular}{|c|c|c|c|}
\hline Model & Date & $\begin{array}{l}\text { Time of } \\
\text { construction } \\
\text { (days) }\end{array}$ & Stage of construction \\
\hline । & $15 / 08 / 2005$ & 0 & Pour of slab 1 \\
\hline$\|$ & 22/09/2005 & 37 & Pour of slab 2 \\
\hline III & $27 / 10 / 2005$ & 73 & Pour of slab 3 \\
\hline IV & $25 / 11 / 2005$ & 101 & Pour of slab 4 and masonry on slab 1 \\
\hline V & $14 / 12 / 2005$ & 120 & Pour of slab 5 \\
\hline $\mathrm{VI}$ & $29 / 12 / 2005$ & 135 & Pour of slab 6 \\
\hline VII & $14 / 01 / 2006$ & 151 & Pour of slab 7 and masonry on slab 2 \\
\hline VIII & $31 / 01 / 2006$ & 167 & Pour of slab 8 and masonry on slab 3 \\
\hline IX & $17 / 02 / 2006$ & 184 & Pour of slab 9 and masonry on slab 4 \\
\hline$x$ & 16/03/2006 & 211 & Pour of slab 10 and masonry on slab 5 \\
\hline$X I$ & $15 / 04 / 2006$ & 240 & Pour of slab 11 and masonry on slab 6 \\
\hline XII & $17 / 07 / 2006$ & 331 & Pour of slab 12 and masonry on slab 7 \\
\hline$X \mid \|^{*}$ & $04 / 10 / 2006$ & 413 & Completed structure and masonry on slab 10 \\
\hline $\mathrm{XIV}^{*}$ & $02 / 07 / 2007$ & 681 & Final stage of the construction \\
\hline
\end{tabular}




\section{Table 3 - Physical parameters of construction materials used}

\begin{tabular}{|lcc|}
\hline Maierial & Property & Adopted value \\
\hline Reinforced concrete & Specific weight $\left(\mathrm{kN} / \mathrm{m}^{3}\right)$ & 25 \\
& Poisson coefficient & 0.2 \\
& fck (MPa) & 30 \\
& Elasticity modulus (GPa) & 30.67 \\
& Diameter (mm) & 15.2 \\
Prestressed cable & fptk (MPa) & 1900 \\
& fpyk (MPa) & 1710 \\
Ceramic masonry & Specific weight $\left(\mathrm{kN} / \mathrm{m}^{3}\right)$ & 18 \\
Blocks of cement & Specific weight $\left(\mathrm{kN} / \mathrm{m}^{3}\right)$ & 22
\end{tabular}

considering prestressing in prestressed concrete elements contributed to the optimization of the task of modeling the structure, due to the simplicity of obtaining the forces and the ease of application in commercial programs for structural analysis.

\section{Results and Discussions}

With the intention of evaluating the effects of settlements on the reactions of supports and normal forces on columns, two hypotheses for the supports were considered in the analysis. In the first hypothesis the supports are considered as non-displaceable, to obtain the reactions on the supports as is done traditionally in structural building projects. The results related to this hypothesis are so called FS in the following figures, which mean fixed supports. In the second hypothesis, the settlements measured at each stage were imposed, as prescribed displacements on the supports, to obtain the effects of the settlements on the reactions of the supports. In all figures beneath, the results obtained by this hypothesis are called as MS which means movable supports. By superimposing the effects of the weight of the structure itself and brickwork, prestressing and the settlements, the effects of the soil-structure interaction were then analyzed.

Figure [7] presents the plan of column locations on the ground floor with the respective numberings. The columns in the central region (columns 1 to 18) have deep foundations and continue along the typical floor, whereas the columns in the external region (columns 19 to 35 ) are supported on footing foundation and end on the $2^{\text {nd }}$ or $3^{\text {rd }}$ floor. In the same figure, in the shadowed regions, the increase in foundation loads predominates. Note that the load transfer from columns occurs between the columns of the central axis of the building and the peripheral columns.
In order two evaluate the magnitude of settlements foundation, Figure [8] presents curves of average settlements of all foundations, assembled by type of foundation. It is possible to remark in this figure that the shallow foundations have mean settlements higher than those of deep foundation in the first stages of the construction and they have a tendency to stabilize in the latest measures. The increase of settlements in shallows foundation after the execution of the third slab suggest that, due the stiffness of the structure, a load transfer have occurred from central piles to peripheral piles. This is a typical behavior of the SSI.

In Figures [9] and [10] the curves of the mean values of reactions on the supports are presented, grouping the columns in cases in which load increase and relief occur, respectively. Noting the maximum values of the means of reactions, one verifies that on the most loaded columns, load relief occurs, while on the less loaded columns increase in load occurs. GUSMÃO [5] considers the trans-

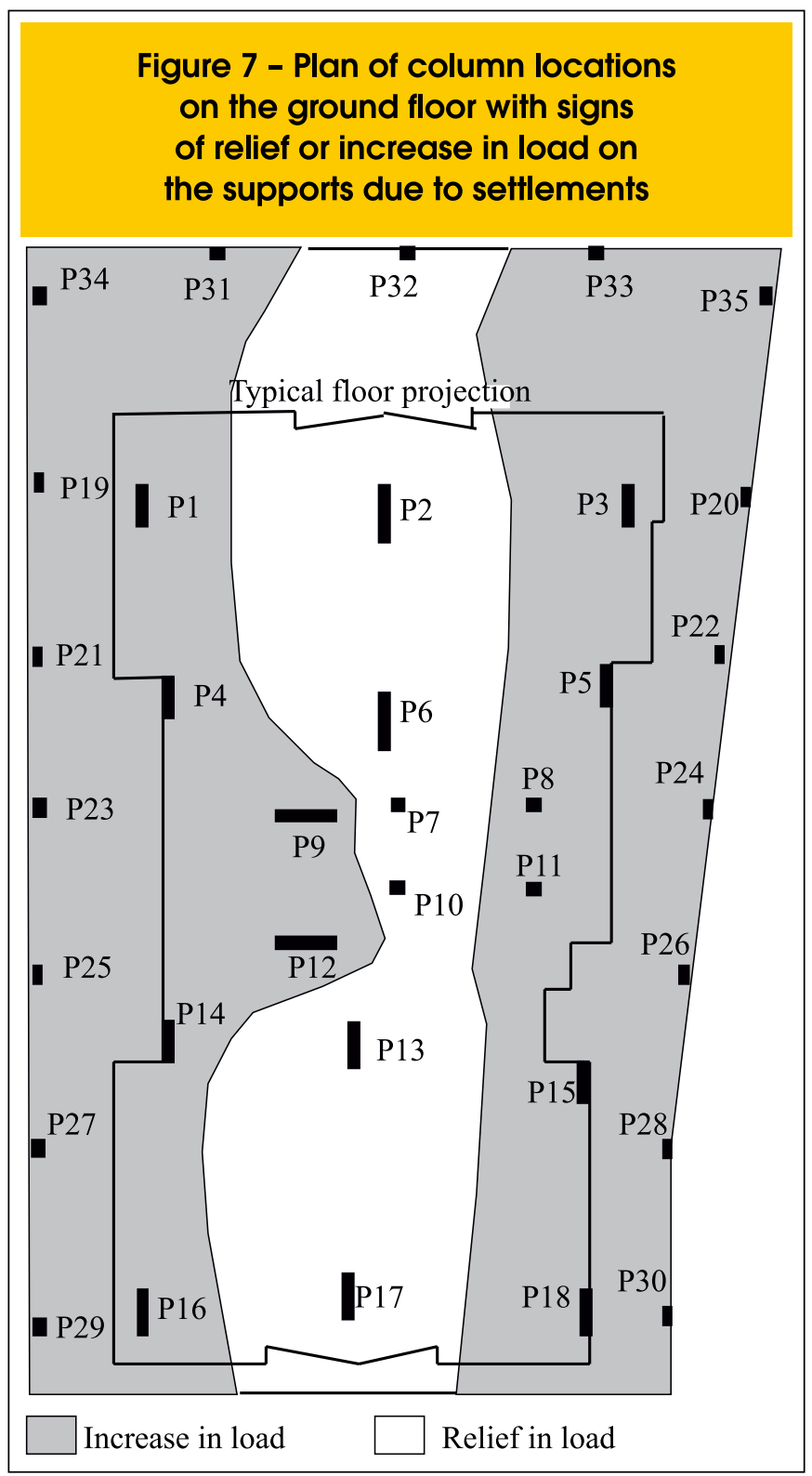




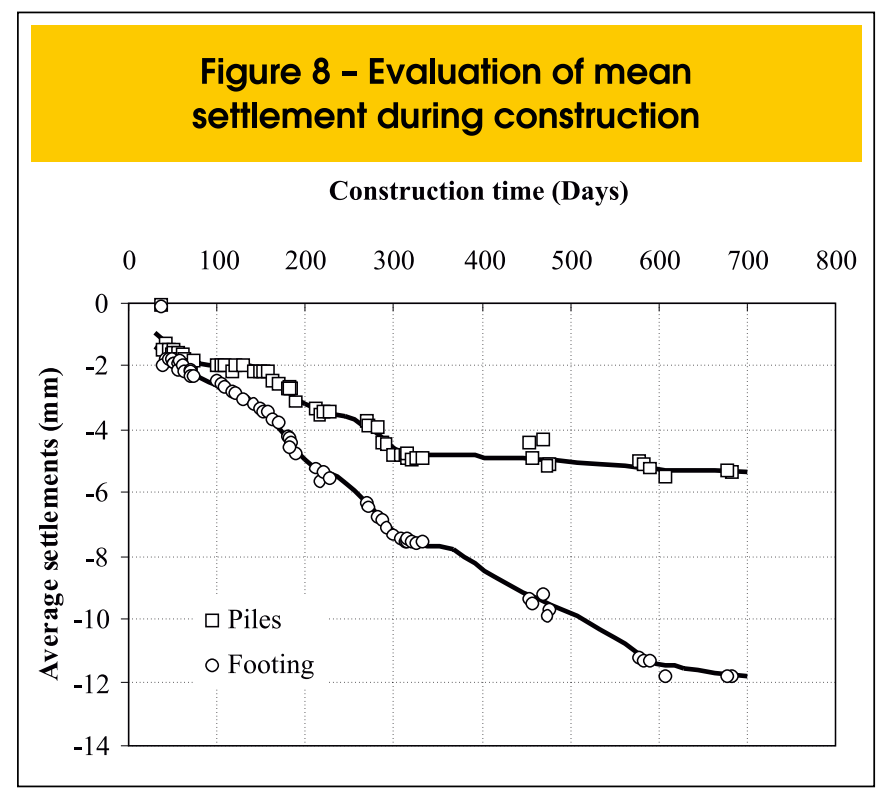

fer of load from more loaded columns to the less loaded columns as one of the main effects of the soil-structure interaction.

To quantify the redistribution of loads of pillars, the coefficient of axial force redistribution (FR) was obtained, defined as:

$$
F R=\left(\frac{R_{c r}-R_{i}}{R_{i}}\right) * 100
$$

where $R_{i}$ is the reaction on the support of column $i$ calculated considering the non-displaceable supports and $R_{c r}$ is the reaction

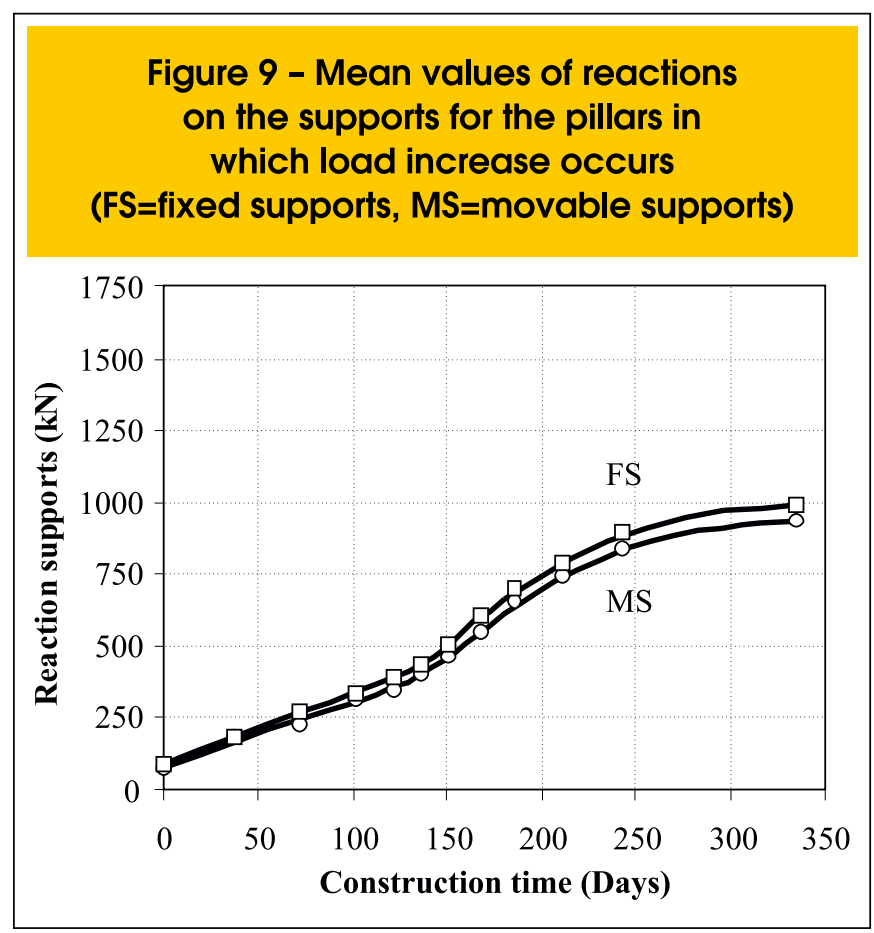

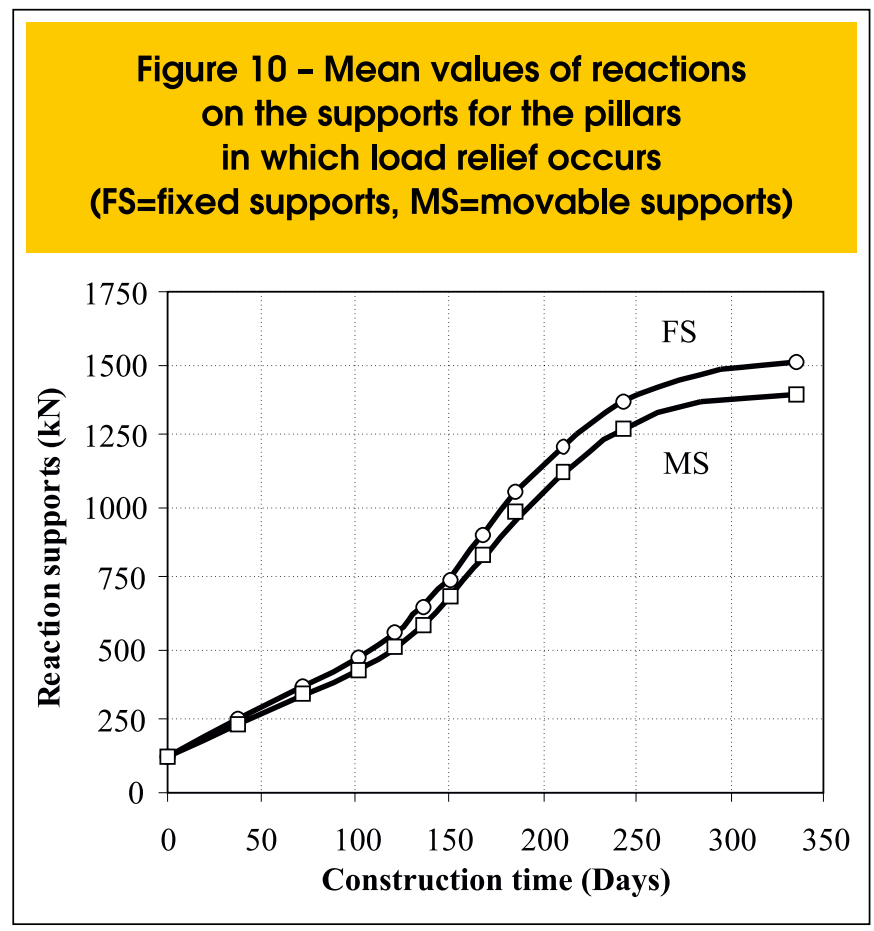

on the support of column $i$ calculated considering the settlements measured during the construction stage. The coefficient $F R$ represents, in percentage, the load increase or relief on the support due to the settlements.

Figure [11] presents the curves of the maximum and minimum values of FR in each stage of modeled construction. Observe that for $\mathrm{FR}$ values higher than zero load increase on the columns occurs, whereas for FR values lower than zero, load relief occurs.

One finds the highest load increases and reliefs in the first stages of construction. One verifies that as the quantity of floors of the

\section{Figure 11 - Variation in maximum load increase and relief during the course of construction}

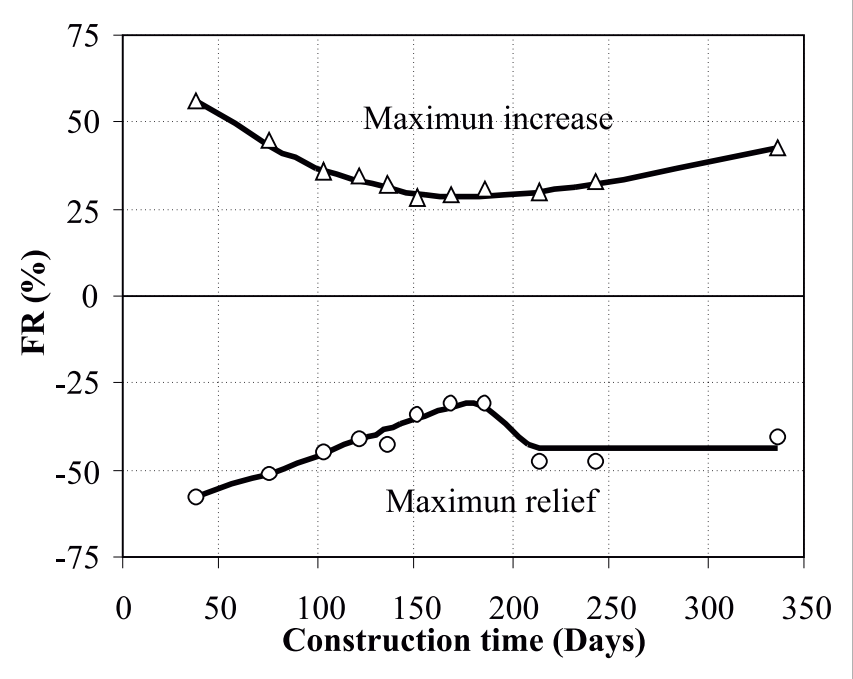


Figure 12 - Mean of FR during the course of the construction

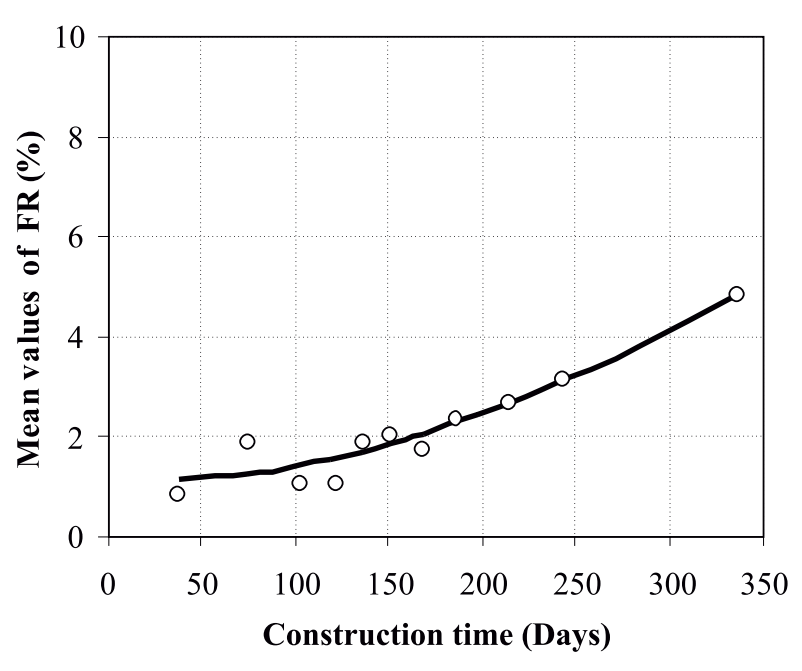

building increases, the amplitude between the values of load increases and reliefs among the columns tends to diminish. Symmetry of the curves is observed in relation to the horizontal axis that passes through the origin, indicating the redistribution of the forces occurs, caused by the structure soil interaction.

It should be noted in this figure a worrying fact. For the last monitoring stage for example (pour of $12^{\text {th }}$. slab) the value of FR for pillars suffering additional load is approximately $43 \%$. This increase is a cause for apprehension from the structural point of view, and therefore merits attention.

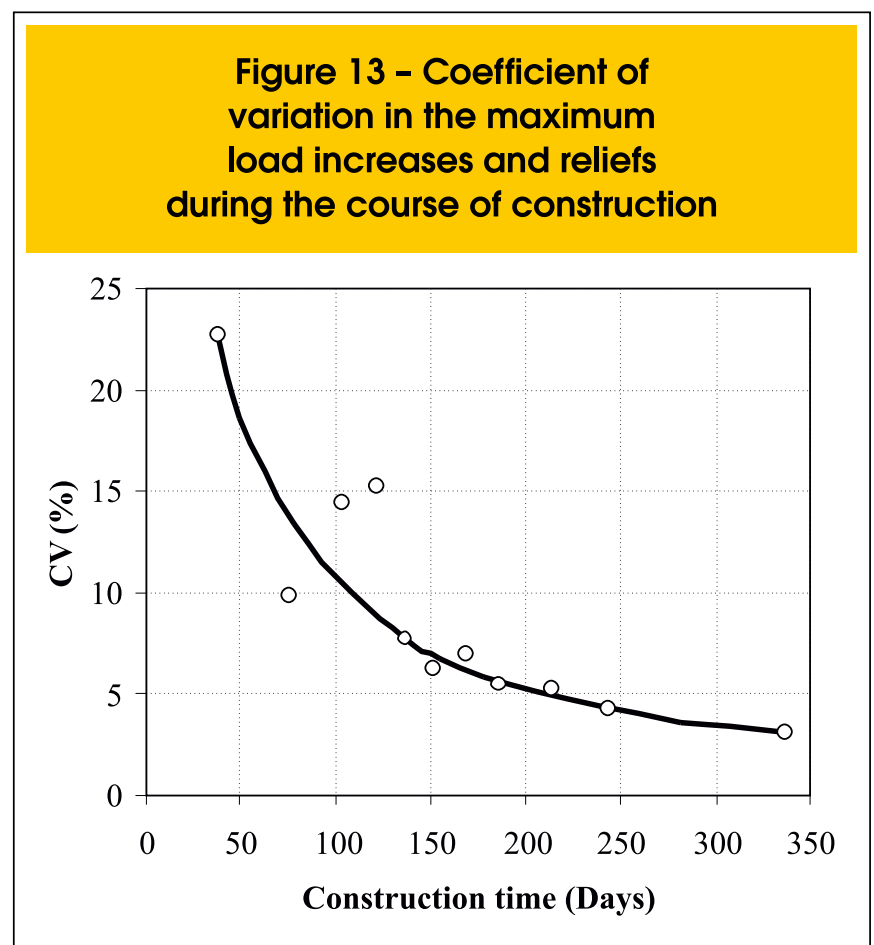

Figure [12] presents the development of the mean FR during the course of the construction. Note the increase in variation of the loads between the two models analyzed over the course of the construction. One verifies that for Stage XII the mean of the FR values corresponds to $5 \%$.

Uniformization of the load redistributions may be found when one analyzes the coefficient of variation (CV) of the redistribution factor for each stage of construction, as presented in Figure [13]. This coefficient of variation is defined by the ratio between the standard deviation and the mean of FRs. One verifies that with the increase in the number of floors, the redistribution factor tends to diminish and stabilize.

The reduction in the variation of load distributions with the increase in the number of floors was also found by MADUREIRA and BEZERRA [14], by the analysis of frames with various numbers of floors. The authors concluded that with the increase in the number of floors in structures, and the consequent increase in rigidity to flexion. The variation in the load redistribution among the columns diminished.

To evaluate the effect of the rigidity of the structure on the variation in loads on the columns along the floors, the variation of axial loads on columns in each floor were analyzed. The columns were grouped according to the number of floors they supported (2, 3 and 12 floors), and according to the effect of the structure soil interaction, in case of load relief or increase. The variation on axial force in percent in respect with the axial forces for fixed support is presented in Figure [14], for the stage with reference to the last concrete slab (12 $12^{\text {th }}$ Floor).

This figure shows a reduction of load in columns $A$, in the central region of the construction, and an increase of load in columns $B$ and $C$, on the peripheral region. This behavior is typically expected due the SSI and shows the influence of the stiffness of the structure in this mechanism.

In this figure the percent of axial forces variation on the columns, whether or not one considers the settlements, keeps almost constant. For central columns, for example, these values remains constant and approximately equal to $4 \%$ until the $9^{\text {th }}$ floor, then this values decrease to zero on $12^{\text {th }}$ floor. For peripheral columns $\mathrm{B}$ and $\mathrm{C}$, load is increased by approximately $4 \%$ and $6.8 \%$ and keeps constant though the stages. The low variation in percentage of axial load due the SSI is realized, however requiring special attention regarding the magnitude of axial load variation because unexpected pathologies could occur in the construction. The constant values until $9^{\text {th }}$ floor for central columns could be explained by the presence of the masonry in the first floors of the edification, as presented in Table 2. Masonry gives rigidity to the structure allowing monolithic behavior of the members and standardizing the changes in axial load due to SSI.

The relief in the variation of normal forces on the columns as one moves further from the foundation level is also presented in the studies of CRESPO [15] and GUSMÃO and CALADO JR [8].

\section{Conclusions}

The aim of this study was to investigate the influence of the structure soil interaction mechanism on the redistribution of loads among the columns, by monitoring the settlements and numerical simulation by computer. Along general lines, it could be found that: 
I - Numerical simulation of the building by models with reference to the execution of each concrete slab, considering the hypotheses of non-displaceable supports and with the settlements applied to each model, it was possible to evaluate these effects.

II - The small settlements that occurred in buildings, frequently disregarded, cause disturbances in the structure, resulting in redistribution of loads among the columns, with consequent uniformization of the settlements.

III - The results of this study proved the importance of joint consideration of the structure and the foundations in the structural analysis of buildings. The small settlements that occurred in buildings, frequently disregarded, caused disturbances in the structure. By numerical simulation redistribution of loads among the columns was found, due to the settlements, showing evidence of transfer of loads from the columns supported on foundations that present greater settlements to those that have smaller settlements.

When observing the effects of the structure soil interaction it was concluded that it is of extreme importance to consider the settlements in the analysis of the structure, as well as in drawing up projects, analyzing the effects on the construction process.

\section{Acknowledgements and Thanks}

The authors of this study thank UENF for the physical and academic structure that favored conducting this study, and also thank CAPES for its support.

\section{References}

[01] MEYERHOF, G. G. (1953) Some Recent Foundation Research and its Application to Design. Structural Engineer, Vol. 31, pp. 151-167; apud GUSMÃO (1994).

[02] CHAMECKI, S. (1954) Consideração da Rigidez da Estrutura no Cálculo dos Recalques da Fundação. In: I Congresso Brasileiro de Mecânica dos Solos e Engenharia deFundações, Porto Alegre, v. 1, pp. 35-80; apud GONÇALVES (2004).

[03] GOSHY, B. (1978) Soil-foundation-structure interaction. Journal of the Structural Division, ASCE, vol.104, n. ST5, pp. 749-761; apud GUSMÃO (2006).

[04] GUSMÃO, A. D. (1994) Aspectos relevantes da interação solo-estrutura em edificações. Revista Solos e Rochas, São Paulo, v.17 (1), p.47-55.

[05] GUSMÃO, A. D. (2006) Desempenho de fundações de edifícios. In: Palestras XIII COBRAMSEG, Curitiba, pp 215-240.

[06] GUSMÃO, A. D., GUSMÃO FILHO, J. A. (1994) Construction sequence effect on settlements of buildings. In. XI ICSMFE, New Delhi, v.3, p.1803-1806; apud GUSMÃO (2006).

[07] DANZIGER, F. A. B.; DANZIGER, B. R.; CRISPEL, F. A. (2000). A medida dos recalques desde o início da construção como um controle de qualidade

\section{Figure 14 - Axial forces variation for the stage with reference to concrete slab 12}

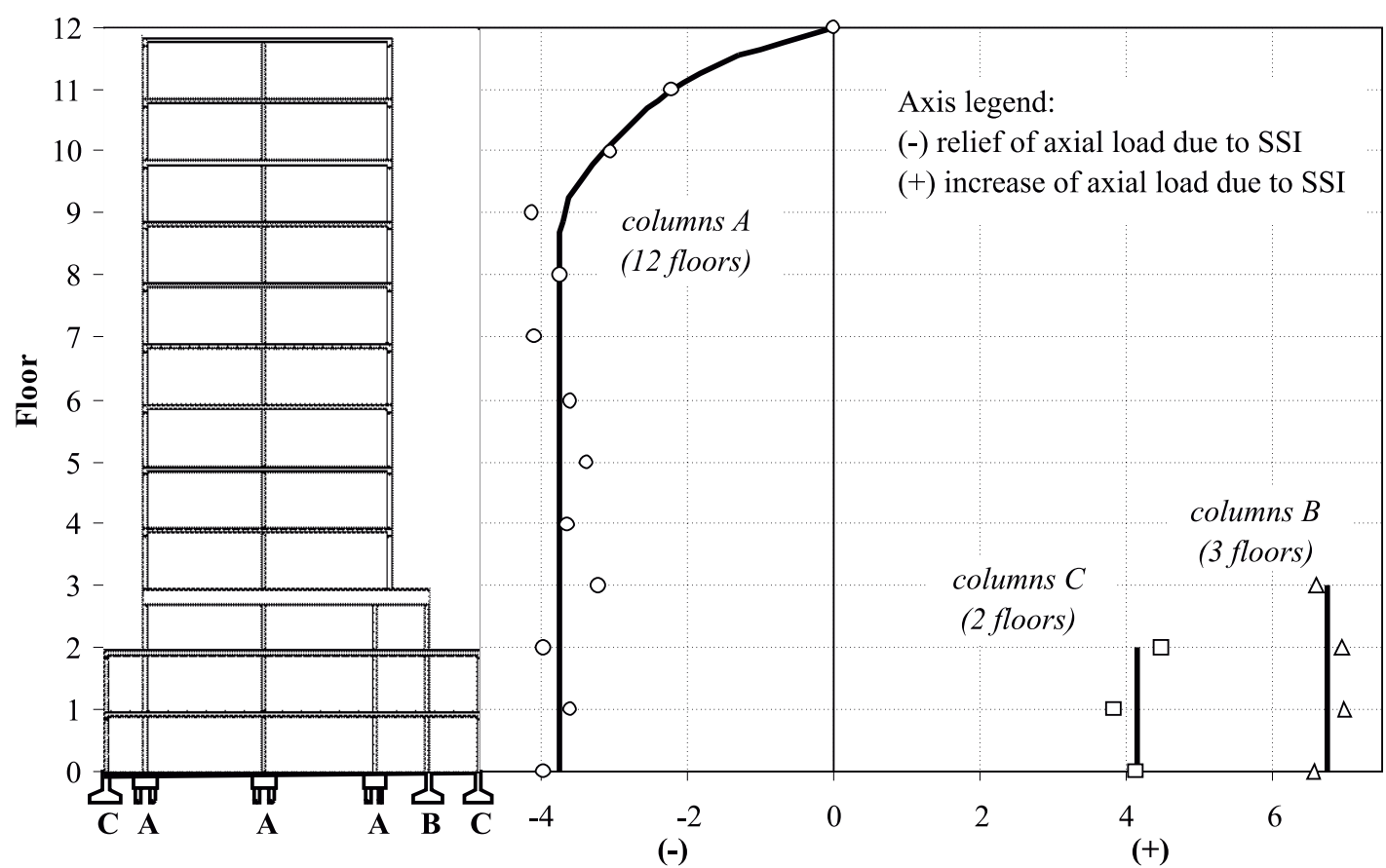

Building representation

Changes in Axial Force (\%) 
das fundações. $4^{\circ}$ Seminário de Engenharia de Fundações Especiais e Geotecnia -SEFE IV, p. 191-202.

[08] GUSMÃO, A. D., CALADO JR., I. H. (2002) Estudo dos efeitos da interação solo estrutura em uma edificação com fundação em terreno melhorado. In. XII COBRAMSEG, São Paulo, SP, ABMS, Anais, v.3, p.1743-1752.

[09] GONÇALVES, J. C. (2004) Avaliação da influência dos recalques das fundações na variação de cargas dos pilares de um edifício. Rio de Janeiro. Dissertação (Mestrado) - COPPE, Universidade Federal do Rio de Janeiro, 126p.

[10] SAVARIS, G., (2008). Monitoração de Recalques de um Edifício e Avaliação da Interação Solo Estrutura. Dissertação (Mestrado) - Campos dos Goytacazes - RJ, Universidade Estadual do Norte Fluminense - UENF, 177p.

[11] ABNT - Brazilian Technical Standards Association (1980). Cargas para o cálculo de estruturas de edificações. Title of the standard: NBR 6120 , Rio de Janeiro, $5 p$.

[12] ABNT - Brazilian Technical Standards Association (2003). Projeto de estruturas de concreto Procedimento. Title of the standard:: NBR 6118, Rio de Janeiro, 221p

[13] MENEGATTI, M. (2004) A protensão como um conjunto de cargas concentradas equivalentes. São Paulo. Dissertação (Mestrado) - Escola Politécnica da Universidade de São Paulo, 126p.

[14] MADUREIRA, E. L., BEZERRA, J. E. (2000). Influência da interação solo estrutura na distribuição de cargas em pilares. In. $4^{\circ}$ Seminário de Engenharia de Fundações Especiais e Geotecnia - SEFE IV, p. $178-184$

[15] CRESPO, V. A. S. (2004) Estudo da sensibilidade de edificações em relação ao solo. Campos dos Goytacazes. Dissertação (Mestrado) Universidade Estadual do Norte Fluminense UENF, 92p. 